Atmos. Chem. Phys. Discuss., 10, 10313-10334, 2010 www.atmos-chem-phys-discuss.net/10/10313/2010/ (C) Author(s) 2010. This work is distributed under the Creative Commons Attribution 3.0 License.
Atmospheric

Chemistry and Physics Discussions

This discussion paper is/has been under review for the journal Atmospheric Chemistry and Physics (ACP). Please refer to the corresponding final paper in ACP if available.

\title{
Enhancement of the volcanogenic "bromine explosion" via reactive nitrogen chemistry (Kīlauea volcano, Hawai'i)
}

G. G. Salerno $0^{1,2}$, C. Oppenheimer ${ }^{2,3,4}$, V. I. Tsanev ${ }^{2,5}$, A. J. Sutton ${ }^{6}$, T. J. Roberts ${ }^{7}$, and T. Elias ${ }^{6}$

${ }^{1}$ Istituto Nazionale di Geofisica e Vulcanologia, sezione di Catania, Piazza Roma, 2, Catania, 95123, Italy

${ }^{2}$ University of Cambridge, Department of Geography, Downing Place, Cambridge, CB2 3EN, UK

${ }^{3}$ Le Studium ${ }^{\circledR}$, Institute for Advanced Studies, Orleans and Tours, France

${ }^{4}$ Institut des Sciences de la Terre d'Orléans, 1a rue de la Férollerie, Orléans, cedex 2, 45071, France

${ }^{5}$ University of Cambridge, Department of Chemistry, Lensfield Road, Cambridge, CB2 1EW, UK

${ }^{6}$ United States Geological Survey, Hawaiian Volcano Observatory, P.O.-Box 51, Hawaii National Park, HI 96718, USA

ACPD

$10,10313-10334,2010$

Enhancement of volcanogenic "bromine explosion" via reactive nitrogen

G. G. Salerno et al.

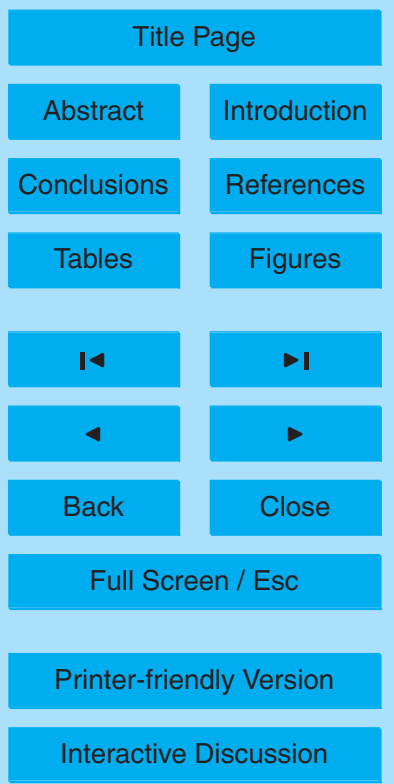


${ }^{7}$ Norwegian Polar Institute, Polar Environmental Centre, Troms $\varnothing, 9296$, Norway

Received: 16 February 2010 - Accepted: 11 March 2010 - Published: 20 April 2010

Correspondence to: G. G. Salerno (salerno@ct.ingv.it)

Published by Copernicus Publications on behalf of the European Geosciences Union.

\section{ACPD}

10, 10313-10334, 2010

\section{Enhancement of volcanogenic "bromine explosion" via reactive nitrogen}

G. G. Salerno et al.

Title Page

Abstract Introduction

Conclusions References

Tables Figures

14

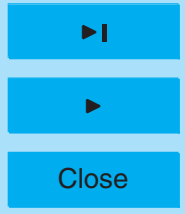

Back

Full Screen / Esc

Printer-friendly Version

Interactive Discussion 


\section{Abstract}

Since the first detection of bromine monoxide in volcanic plumes attention has focused on the atmospheric synthesis and impact of volcanogenic reactive halogens. We report here new measurements of $\mathrm{BrO}$ in the volcanic plume emitted from Kilauea

5 volcano - the first time reactive halogens have been observed in emissions from a hotspot volcano. Observations were carried out by ground-based Differential Optical Absorption Spectroscopy in 2007 and 2008 at Pu'u'O'ō crater, and at the 2008 magmatic vent that opened within Halema'uma'u crater. BrO was readily detected in the Halema'uma'u plume (average column amount of $3 \times 10^{15}$ molec cm ${ }^{-2}$ ) and its abundance was strongly correlated with that of $\mathrm{SO}_{2}$. However, anticorrelation between $\mathrm{NO}_{2}$ and $\mathrm{SO}_{2}$ (and $\mathrm{BrO}$ ) abundances in the same plume strongly suggest an active role of $\mathrm{NO}_{\mathrm{x}}$ in reactive halogen chemistry. The calculated $\mathrm{SO}_{2} / \mathrm{BrO}$ molar ratio of $\sim 1600$ is comparable to observations at other volcanoes, although the $\mathrm{BrO}$ mixing ratio is roughly double that observed elsewhere. While BrO was not observed in the Pu'u'O'ō 15 plume this was probably merely a result of the detection limit of our measurements and based on understanding of the Summit and East Rift magmatic system we expect reactive halogens to be formed also in the Pu'u'Ō'o emissions. If this is correct then based on the long term $\mathrm{SO}_{2}$ flux from Pu'u'Ō'ō we calculate that Kilauea emits $\sim 480 \mathrm{Mg} \mathrm{yr}^{-1}$ of reactive bromine and may thus represent an important source to the tropical Pacific troposphere.

\section{Introduction}

Volcanoes release significant quantities of reactive gases and particles into the atmosphere, with fluxes and relative abundances that tend to reflect levels of volcanic activity, tectonic setting and extent of magmatic-hydrothermal interaction (e.g., Carroll and Holloway, 1994; Mather et al., 2003; Oppenheimer, 2003). Volcanism has played a crucial role in the formation of the Earth's atmosphere (e.g., Cadle, 1980; Martí and

\section{Enhancement of volcanogenic "bromine explosion" via reactive nitrogen}

G. G. Salerno et al.

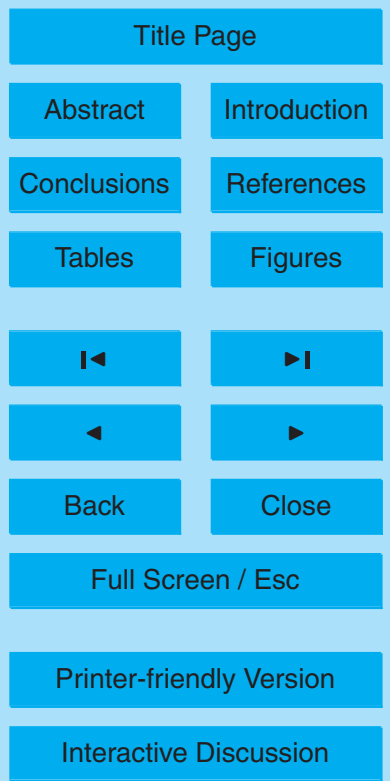


Ernst, 2005), and continues to play a significant role in the composition and radiative transfer of the atmosphere (e.g., Kelly et al., 1997; Grainger and Highwood, 2003). The study of volcanic emissions is thus essential not only for modelling eruptive activity and for hazard evaluation but also to evaluate fully their impacts on the Earth 5 system. With the recent discovery of reactive halogens, notably $\mathrm{BrO}$, in volcanic emissions from both passive (e.g., Bobrowski et al., 2003) and explosive (e.g., Theys et al., 2009) volcanic degassing, the role of volcanism in atmospheric ozone abundance, acidity and oxidising capacity has become the focus of interest in the wider context of the roles of halogens in the troposphere. Chlorine and fluorine species are among 10 the most abundant volatile species in volcanic emissions following water vapour, $\mathrm{CO}_{2}$ and $\mathrm{SO}_{2}$ (e.g., Symonds et al., 1994). Heavy halogens, although present in lesser quantities, nevertheless are expected to partition strongly into magmatic gas phases (Bureau et al., 2003), and assume special significance on account of their important atmospheric chemistry. Typically, halogens are more abundant in gases released by convergent-plate-sited volcanoes, due to their associated water and halogen-rich magmas compared with divergent-plate-sited and hot-spot volcanoes (e.g., Hilton et al., 2002; Oppenheimer, 2003). Despite the noteworthy influence of halogens in magmatic processes (Hedenquist and Lowenstern, 1994; Aiuppa, 2008a) and atmosphere chemistry (e.g., Von Glassow et al., 2009), their role in volcano dynamics remains poorly constrained (Aiuppa et al., 2008b). Owing to the low abundance of heavy halogens in magma, more is known of their behaviour in convergent-plate magmas (e.g., Carol and Holloway, 1994; Muranatsu and Wedepohl, 1998). The inventories of bromine content in magma (e.g., Wedepohl, 1974; Wehrmann, 2005), in volcanic gas (e.g., Sugiura et al., 1963; Snyder et al., 2002), and Br-oxide emission rates (e.g, Bobrowski et al., 2007b), remain weakly constrained (Pyle and Mather, 2009).

Thanks to the proliferation of low cost ultraviolet spectrometers and associated analytical techniques such as Differential Optical Absorption Spectroscopy (DOAS) in the last decade (e.g., Platt et al., 1994; Plane and Saiz-Lopez, 2006) several volcanogenic $\mathrm{BrO}$ measurements have been carried out. In particular, since the first detection of $\mathrm{BrO}$

\section{Enhancement of volcanogenic "bromine explosion" via reactive nitrogen}

G. G. Salerno et al.

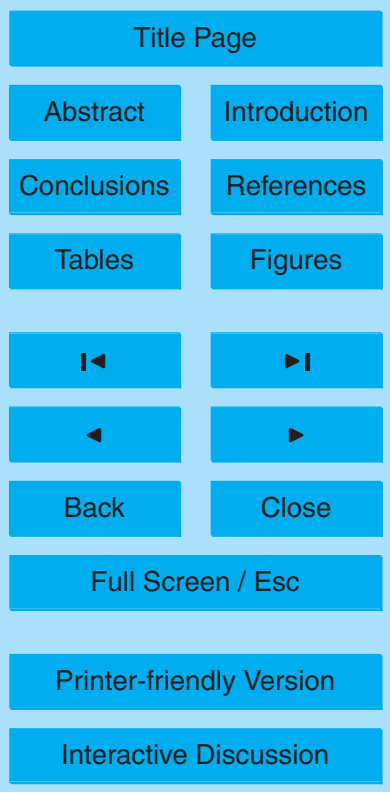

\section{6}


by UV DOAS (at Soufrière Hills Volcano, Montserrat; Bobrowski et al., 2003), numerous efforts have been made to advance the knowledge of the origin and contribution of this reactive halogen in volcanic plume chemistry. Several studies have argued that $\mathrm{BrO}$ is not a primary magmatic species, but that it forms in volcanic plumes via the 5 so-called "bromine explosion" (Wennberg, 1999), i.e., by heterogeneous, photochemical processing originating with oxidation of a small quantity of magmatic $\mathrm{HBr}$ (e.g., Oppenheimer et al., 2006; Bobrowski et al., 2007a; Roberts et al., 2009). Recent observations at Masaya volcano where $\mathrm{BrO}$ was observed only during daylight hours provide strong evidence for the proposed chemical schemes (Kern et al., 2008).

10 Here we report and discuss the first observations of BrO emission from a hotspot volcano, namely Kilauea (Hawai'i, USA). These were obtained by ground-based UV spectroscopic observations carried out in 2007 and 2008 for plumes emitted by both the Pu'u'Ō'o crater (on the East Rift Zone) and by a new magmatic vent that opened in March 2008 within Halema'uma'u crater. We discuss the reactive bromine observations 15 in light of striking results concerning the co-retrieved abundances of $\mathrm{NO}_{2}$.

\section{Observation sites and methods}

During our fieldwork, Killauea was active along the East Rift in 2007, and at both the Summit and East Rift in 2008. Pu'u'Ō'ō has been active since 1983 (Heliker et al., 2003), whereas Kilauea summit activity began on 12 March 2008 (Orr et al., 2008; Patrick et al., 2008; Poland et al., 2008). The Summit and East Rift activity and degassing have been the subject of many studies, which demonstrate that much of the magmatic supply of $\mathrm{CO}_{2}$ is released at the summit (e.g., Gerlach and Graeber, 1985). UV spectra were acquired within $1-1.5 \mathrm{~km}$ of both the Pu'u'Ō'o crater on 3 September 2007 and Halema'uma'u crater on 13 May 2008 (Fig. 1). Surveys were performed between 09:00 and 16:00 LT (Local Time), dictated largely by the prevailing weather conditions and wind direction. Wind data were sourced from NOAA (http://ready.arl.noaa.gov/READYcmet.php).

\section{Enhancement of volcanogenic "bromine explosion" via reactive nitrogen}

G. G. Salerno et al.

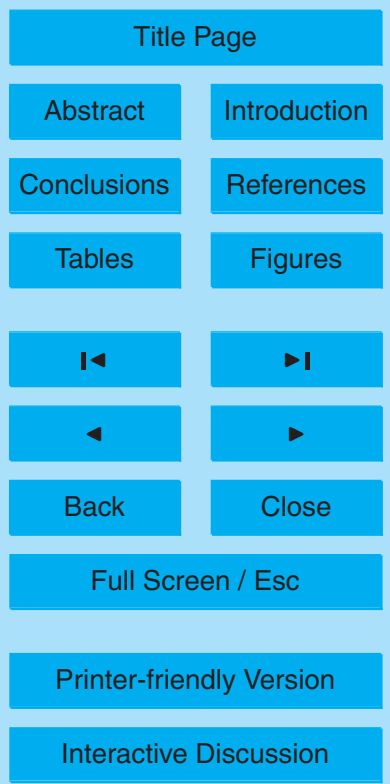

\section{7}


$\mathrm{SO}_{2}, \mathrm{BrO}$ and $\mathrm{NO}_{2}$ Slant Column Amounts (SCA) were retrieved from successively collected passive UV skylight spectra recorded by an Ocean Optics USB2000 spectrometer with spectral range $295-375 \mathrm{~nm}$ and $\sim 0.44 \mathrm{~nm}$ (full-width-at-half-maximum) nominal resolution. The spectrometer was housed in a thermo-stabilised enclosure 5 (held at $15^{\circ} \mathrm{C}$ ) and coupled by a fibre optic bundle to a single lens telescope (full plane field of view of $8 \mathrm{mrad}$ ). The azimuthal viewing directions were north-west and east in 2007 and 2008, respectively; the elevation angle of the field of view was $\sim 30^{\circ}$. Each spectrum was recorded with an overall time step of $\sim 20 \mathrm{~s}$ by exposing the detector for $\sim 200 \mathrm{~ms}$ and co-adding up to 100 successive individual spectra (so as to maximise 10 the signal-to-noise-ratio whilst avoiding saturation in the wavelength region used in the retrieval). In each survey 3-4 datasets were recorded, each consisting of $\sim 80$ spectra collected over a $\sim 20$ min period.

The cooling and thermo-stabilisation reduced the associated dark current and avoided temperature drifts that are known to affect the performance of the detector 15 and optical bench. For a few datasets in both surveys, the thermo-stabilised instrument was not used, in which case we collected Clear Sky Reference (CSR, out of plume), dark and offset spectra, routinely at the start and the end of each data set sampling to account for instrumental drift. The CSR spectra were recorded by pointing the telescope away from the plume with the same elevation used to observe the plume.

Each recorded spectrum was evaluated following standard DOAS methodology (e.g., Noxon, 1975; Perner et al., 1979; Platt and Stutz, 2008) using the WinDOAS V2.10 software package (Fayt and Roozendael, 2001). The Ring spectrum (e.g., Solomon 1987; Fish and Jones, 1995) was calculated from the CSR following the approach of Chance et al. (1998). Both laboratory spectra of $\mathrm{SO}_{2}, \mathrm{BrO}, \mathrm{O}_{3}$, and $\mathrm{NO}_{2}(293,298$, 293 and 223 K, respectively; Wahner et al., 1998; Bogumil et al., 2003) and the Ring spectrum were convolved to the spectrometer's resolution. In the fitting process, a first order linear offset was also included to account for possible instrumental and/or atmospheric stray light, residual dark current and for different (time variant) Rayleigh/Mie contributions in the recorded spectra. Each spectrum was shifted and stretched until

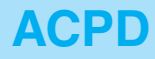

10, 10313-10334, 2010

\section{Enhancement of volcanogenic "bromine explosion" via reactive nitrogen}

G. G. Salerno et al.

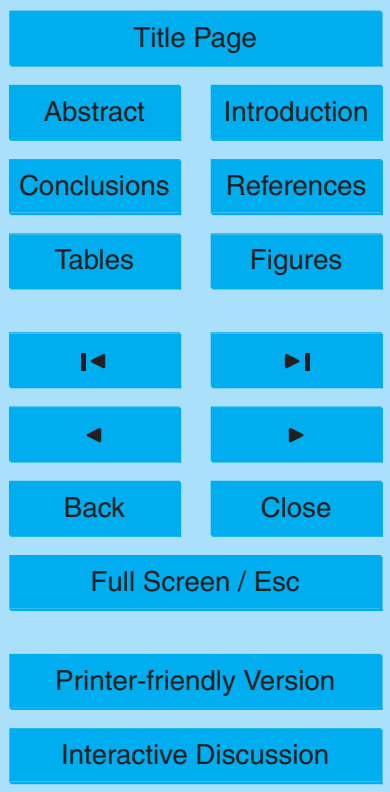


the best fit was achieved. The optimal fitting windows for $\mathrm{SO}_{2}(305.0-316.0 \mathrm{~nm})$, and $\mathrm{BrO}$ and $\mathrm{NO}_{2}(345.0-358.0 \mathrm{~nm})$ were selected to avoid interferences between gases during the retrieval, and yielded near random structures with minimal standard deviation in the residuals. Additionally, $\mathrm{BrO}$ and $\mathrm{NO}_{2}$ were retrieved for a wider spectral 5 window (330-370 nm) to check for artefacts in the retrieved column amounts. Figure 2 shows an example of the $\mathrm{BrO}$ and $\mathrm{NO}_{2}$ fit over the $345.0-358.0 \mathrm{~nm}$ spectral range for a spectrum collected at Halema'uma'u crater on 13 May 2008.

\section{Results}

In Table 1, we compile the results obtained for the Pu'u'Ō'o and Halema'uma'u 10 crater measurements together with the prevailing environmental and plume characteristics. The Pu'u'O'ō spectra yield a mean $\mathrm{SO}_{2}$ abundance around 4 times lower than those measured at the summit $\left(\sim 3 \times 10^{18}\right.$ molec $\left.\mathrm{cm}^{-2}\right)$ and did not reveal $\mathrm{BrO}$ or $\mathrm{NO}_{2}$. Conversely, at Halema'uma'u crater, $\mathrm{BrO}$ was successfully detected (mean of $3 \times 10^{15}$ molec $\mathrm{cm}^{-2}$ ) as well as negative (differential) amounts of $\mathrm{NO}_{2}$ (mean of $15-6 \times 10^{16}$ molec $\mathrm{cm}^{-2}$ ). Note that negative abundances signify lower $\mathrm{NO}_{2}$ relative to the background.

Figure 3 shows $\mathrm{SO}_{2}$ versus BrO SCA measured at Halema'uma'u crater in 2008. The derived $\mathrm{SO}_{2} / \mathrm{BrO}$ plume molar ratio is $1600 \mathrm{~mol} \mathrm{~mol}^{-1}\left(R^{2}: 0.84\right)$ equivalent to a $\mathrm{S} / \mathrm{Br}$ mass ratio of 645 .

20 Based on weekly $\mathrm{SO}_{2}$ flux measurements of the Halema'uma'u plume (Elias et al., 2010), this suggests a $\mathrm{BrO}$ emission rate of $\sim 8 \mathrm{~g} \mathrm{~s}^{-1}$. Note that the linear regression of the $\mathrm{SO}_{2}$ versus $\mathrm{BrO}$ data does not go through the origin. We interpret this to suggest the presence of $\mathrm{BrO}$ in the CSR spectrum, possibly hinting at differential rates of chemical processing of $\mathrm{SO}_{2}$ and $\mathrm{BrO}$ in the local atmosphere. Taking this into account as well as the likelihood that other reactive $\mathrm{Br}$ species are present in the plume, our

\section{ACPD}

$10,10313-10334,2010$

\section{Enhancement of volcanogenic "bromine explosion" via reactive nitrogen}

G. G. Salerno et al.

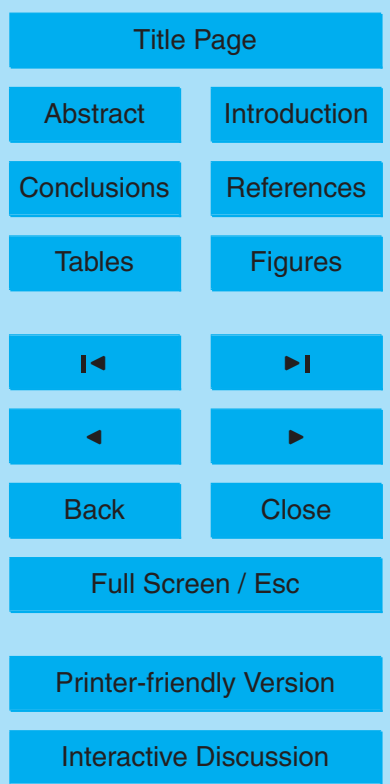


estimated $\mathrm{BrO}$ emission rate for the summit plume at Kilauea underestimates the total reactive bromine flux.

Taking the mean measured $\mathrm{BrO}$ and $\mathrm{SO}_{2} \mathrm{SCA}$ and estimated optical path length through the plume of $600 \mathrm{~m}$, the corresponding mean in-plume $\mathrm{BrO}$ and $\mathrm{SO}_{2}$ mixing 5 ratios were $\sim 2.3$ and 2140 ppbv, respectively.

Nitrogen oxides play significant roles in reactive halogen chemistry - for instance, high levels of $\mathrm{NO}_{\mathrm{x}}$ increase production of $\mathrm{BrONO}_{2}$, which accelerates the bromine explosion, (Oppenheimer et al., 2006; Roberts et al., 2009). Elevated $\mathrm{NO}_{\mathrm{x}}$ levels (in excess of $100 \mathrm{ppbv}$ ) have also been associated with the active lavas at Kilauea (Hue10 bert et al., 1999; Witham, 2005), thus we co-retrieved $\mathrm{NO}_{2}$ in the UV spectra with $\mathrm{BrO}$ to explore for possible effects. We found $\mathrm{NO}_{2}$ strongly negatively correlated with both $\mathrm{SO}_{2}\left(R^{2}=0.87\right.$; Fig. 4a) and $\mathrm{BrO}\left(R^{2}=0.84\right.$; Fig. $\left.4 \mathrm{~b}\right)$. As discussed in the next section, we believe that this striking finding reflects local depletion of $\mathrm{NO}_{\mathrm{x}}$ as a result of reactive bromine chemistry that acts to promote BrO formation.

\section{Discussion}

The first question to address is why BrO was detected at the Halema'uma'u vent but not at Pu'u'O'ō. The most likely explanation is that the optical density of the plume gas species was around 4 times higher in the case of the observations at the summit crater, thus making it easier to detect associated levels of BrO. Given that previous studies have not revealed any evidence for significant fractionation of halogens between the summit and rift zone magmatic degassing (see data compilation in Symonds et al., 1994), we consider that BrO is very likely present in the (daytime) Pu'u'O'o plume but not in sufficient abundance to detect readily with our instrumental set up (consider that the maximum SCA of $\mathrm{SO}_{2}$ detected at Pu'u'O'ō was $3 \times 10^{18} \mathrm{molec} \mathrm{cm}^{-2}$ 25 (Table 1) and consult Fig. 3, and it is readily apparent that conclusive detection of $\mathrm{BrO}$ at Pu'u'Ō'o would have been challenging for our spectrometers (the detection limit of $\mathrm{BrO}$ is $\sim 3 \times 10^{14} \mathrm{molec}^{-2}$ ).

\section{Enhancement of volcanogenic "bromine explosion" via reactive nitrogen}

G. G. Salerno et al.

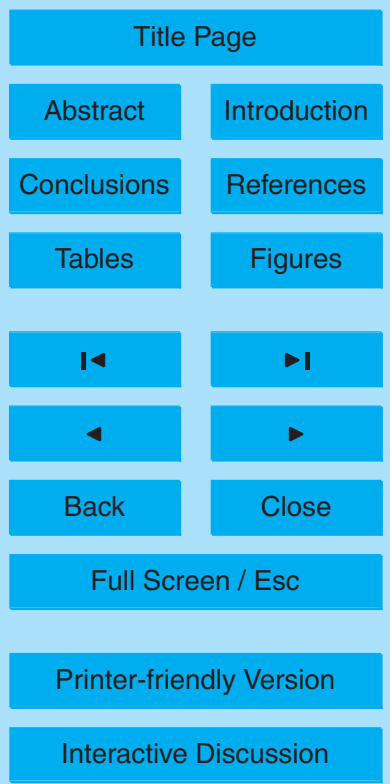

\section{0}


Other factors can contribute to the detection of reactive halogen species, including sensitivity and selectivity of the spectrometer and the spectroscopy, as well as diurnal, seasonal and meteorological factors (e.g., $\mathrm{RH}$, temperature, actinic flux, and cloudiness, which can affect the quality of the CSR; see Bobrowksi and Platt, 2007; Kern et 5 al., 2008; Von Glasow et al., 2009). In addition, the section of the plume transected (margins versus core) and its young age (i.e., distance from source and wind speed less than $2 \mathrm{~min}$ ) can significantly affect the observed $\mathrm{SO}_{2} / \mathrm{BrO}$ ratio (Bobrowski et al., 2007b, 2009; Oppenheimer et al., 2006; Vogel et al., 2008), as well as the overall source flux, which affects plume-air mixing (Bani et al., 2009). Our observations per10 tain to plume ages of $\sim 2-8$ min during which time the $\mathrm{Br}$ explosion is underway; thus, observed $\mathrm{SO}_{2} / \mathrm{BrO}$ ratios may be quite sensitive to the exact plume age (at Mt. Etna, Oppenheimer et al., 2006, observed BrO formation within 2-3 min of emission from source). Variability in air entrainment into the plume likely accounts for some of the observed scatter in the plot of $\mathrm{SO}_{2}$ versus BrO seen in Fig. 3.

15 Note that the plumes at both Summit and East Rift were occasionally ashy and dense and the admixture of water droplets and aerosols resulted in high plume opacity.

If we assume that the measured $\mathrm{SO}_{2} / \mathrm{BrO}$ ratio characterises the near source emission for eruptive vents on Kilauea, then we can take the long-term $\mathrm{SO}_{2}$ flux observed for the volcano (0.62 $\mathrm{Tg} \mathrm{yr}^{-1}$; Sutton et al., 2001; Elias and Sutton, 2002, 2007) and the

$20 \mathrm{~S} / \mathrm{Br}$ mass ratio to calculate a nominal minimum production of $\sim 15 \mathrm{~g} \mathrm{~s}^{-1}$ of reactive $\mathrm{Br}$ (equivalent to $\sim 480 \mathrm{Mg} \mathrm{yr}^{-1}$ ). This is within the range of estimates of other volcanoes, including Soufrière Hills Volcano and Mt. Etna (Bobrowski et al., 2003; Oppenheimer et al., 2006).

Gerlach (2004) predicted that although non-arc basaltic magmas at $1100-1200^{\circ} \mathrm{C}$ 25 are expected to contain less $\mathrm{HBr}$ compared with arc gases, the Kilauea plume should contain reactive halogens in comparable quantities to those of arc volcanoes on account of the oxidising capacity associated with its high $\mathrm{SO}_{2}$ abundance. His predictions are thus borne out by our detection of $\mathrm{BrO}$.

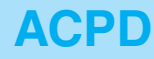

10, 10313-10334, 2010

\section{Enhancement of volcanogenic "bromine explosion" via reactive nitrogen}

G. G. Salerno et al.

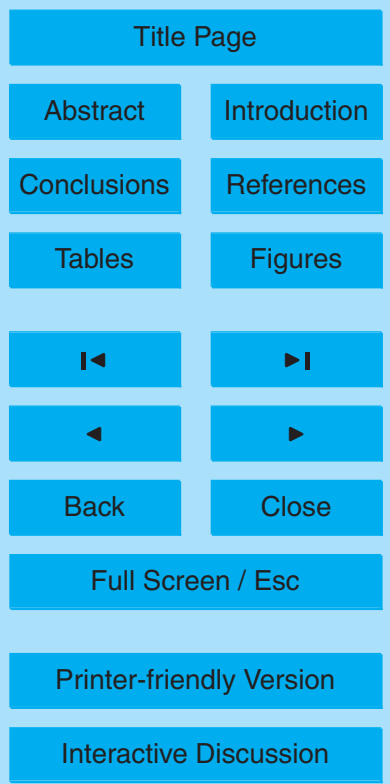


A further key issue to address regarding the observations is the anticorrelation between $\mathrm{BrO}$ (and $\mathrm{SO}_{2}$ ) and $\mathrm{NO}_{2}$ abundance in the retrievals of the differential spectra. The pattern strongly suggests a deficit of $\mathrm{NO}_{2}$ within the plume compared to an elevated background. The mean "missing" $\mathrm{NO}_{2}$ in the plume is $\sim 6 \times 10^{16}$ molec cm ${ }^{2}$ (Ta5 ble 1). This is equivalent to a mixing ratio in the ambient atmosphere at Kilauea summit of around $50 \mathrm{ppbv}$. This is well in excess of the typical $\mathrm{NO}_{\mathrm{x}}$ mixing ratio in the Hawaiian free troposphere (e.g., <1 ppbv measured at the Mauna Loa Observatory; Carroll et al., 1992) but $\mathrm{NO}_{\mathrm{x}}$ levels of $10 \mathrm{~s}$ to a few $100 \mathrm{~s}$ of ppbv have been reported in the immediate vicinity of Kilauea associated with thermal fixation of atmospheric nitrogen at the high 10 temperature surfaces of active lava (Hubert et al., 1999). Witham (2005) reported $\mathrm{NO}_{2}$ mixing ratios measured along the Chain of Craters Road in the Hawaii National Park that average $\sim 150$ ppbv; even background sites had $\mathrm{NO}_{2}$ levels of around $24 \mathrm{ppbv}$. If these observations are indicative then there appears to be plenty of $\mathrm{NO}_{\mathrm{x}}$ in the local atmosphere at Kilauea to account for our observed deficit in the young volcanic plumes.

15 Given the parallel observations of $\mathrm{BrO}$ in the plume, we speculate that the differential spectra indicating $\mathrm{NO}_{2}$ loss in the plume reflect rapid titration of $\mathrm{NO}_{2}$ out of entrained ambient air via the following chemical schemes (Oppenheimer et al., 2006; Roberts et al., 2009):

$\mathrm{BrO}+\mathrm{NO}_{2} \rightarrow \mathrm{BrONO}_{2}$

$\mathrm{BrONO}_{2}+\mathrm{HBr}_{(\text {aerosol })} \rightarrow \mathrm{Br}_{2}+\mathrm{HNO}_{3}$

$\mathrm{Br}_{2} \rightarrow \mathrm{Br}+\mathrm{Br}$

$\mathrm{Br}+\mathrm{O}_{3} \rightarrow \mathrm{BrO}+\mathrm{O}_{2}$

$\mathrm{NO}_{2}$ and $\mathrm{BrO}$ combine to form $\mathrm{BrONO}_{2}$ which reacts with $\mathrm{HBr}$ in aerosol via a multistage process to form $\mathrm{HNO}_{3}$ and $\mathrm{Br}_{2}$. Photolysis of $\mathrm{Br}_{2}$ (once released to the gas phase) generates $\mathrm{Br}$ radicals that react with ozone to form $\mathrm{BrO}$, with an overall doubling of $\mathrm{BrO}$ in this autocatalytic cycle (see Roberts et al., 2009). In this way, the presence of

\section{Enhancement of volcanogenic "bromine explosion" via reactive nitrogen}

G. G. Salerno et al.

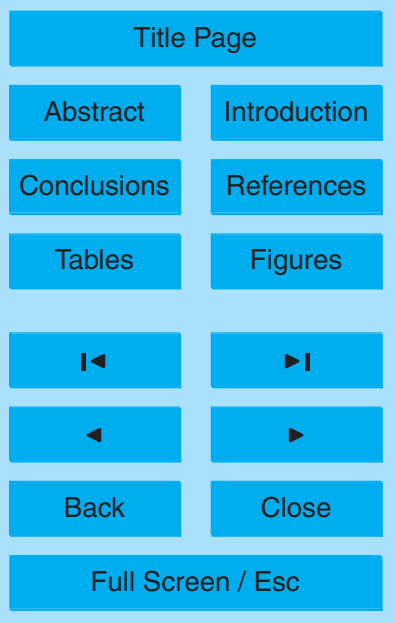

Printer-friendly Version

Interactive Discussion 
$\mathrm{NO}_{\mathrm{x}}$ promotes the bromine explosion and may represent a relevant process enhancing reactive bromine production at Kilauea and other volcanoes where high temperature lava surfaces or high temperature gas jets generate $\mathrm{NO}_{x}$ (Huebert et al., 1999; Mather et al., 2004; Oppenheimer et al., 2005; Martin et al., 2006, 2009). Note that dissoci5 ation, or photolysis of $\mathrm{BrONO}_{2}$ can also occur (regenerating $\mathrm{BrO}$ and $\mathrm{NO}_{2}$, or $\mathrm{Br}$ and $\mathrm{NO}_{3}$ ), but that the reaction of $\mathrm{BrONO}_{2}$ on aerosol is sufficiently rapid under the acidic, high-aerosol loading of volcanic plumes to promote the bromine explosion. The presence of $\mathrm{NO}_{\mathrm{x}}$ also alters the distribution of reactive bromine species between different forms, for example increasing $\mathrm{BrONO}_{2}$ at the expense of $\mathrm{BrO}$. Thus, despite promoting 10 the overall bromine explosion, volcanogenic $\mathrm{NO}_{x}$ can reduce $\mathrm{BrO}$ abundance making it harder to detect by UV spectroscopy.

Because of the path-integrated nature of the DOAS measurements it is difficult to confirm this hypothesis with the data available to us but the evidence for complex chemical pathways involving halogens, $\mathrm{NO}_{\mathrm{x}}, \mathrm{NO}_{\mathrm{y}}$ and ozone in plumes is mounting 15 (e.g., Oppenheimer et al., 2010). Careful in situ measurements, combined with model studies, are required to resolve the details. Model simulations (Roberts et al., 2009) of volcanic plume halogen chemistry have predicted in-plume $\mathrm{NO}_{2}$ depletion and formation of nitric acid $\left(\mathrm{HNO}_{3}\right)$ via the $\mathrm{BrONO}_{2}$ reaction scheme, supporting our observations. The combined observations and model simulations thus provide an explanation for elevated concentrations of $\mathrm{HNO}_{3}$ that were reported at other volcanoes, including Villarrica, Masaya, Etna Láscar and Erebus (Mather et al., 2004; Oppenheimer et al., 2010), and cannot be explained by high-temperature chemistry alone (Martin et al., 2006). These findings highlight the importance of $\mathrm{NO}_{x}$ for BrO-chemistry in volcanic plumes, and identify $\mathrm{NO}_{\mathrm{x}}$ to $\mathrm{HNO}_{3}$ conversion as a consequence of volcanic plume halogen chemistry, in addition to known impacts such as ozone depletion.

\section{ACPD}

10, 10313-10334, 2010

\section{Enhancement of volcanogenic "bromine explosion" via reactive nitrogen}

G. G. Salerno et al.

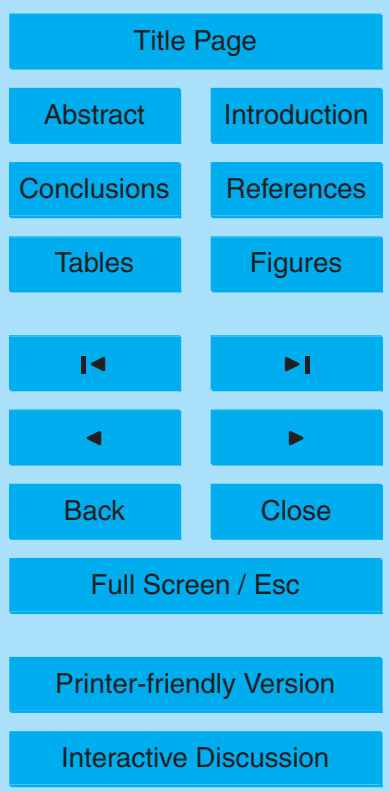




\section{Concluding remarks}

In 2007 and 2008, we carried out UV spectroscopy measurements of the volcanic plume emitted by Pu'u'Ō'ō crater and by the new magmatic vent that opened in March 2008 within the Kilauea Summit caldera. While BrO was not conclusively detected 5 at Pu'u'O'ō, we observed BrO slant column amounts of $10^{14}$ to $10^{15} \mathrm{molec} \mathrm{cm}^{-2}$ and $\mathrm{BrO} / \mathrm{SO}_{2}$ molar ratio of $1600 \mathrm{~mol} \mathrm{~mol}^{-1}$ for the Summit plume. We observed apparent depletion of $\mathrm{NO}_{2}\left(\sim 6 \times 10^{16} \mathrm{molec} \mathrm{cm}^{-2}\right)$, equivalent to $\sim 50 \mathrm{ppbv}$ of $\mathrm{NO}_{2}$ loss within the plume, with amounts strongly correlated with $\mathrm{SO}_{2}$ and $\mathrm{BrO}$ abundance suggesting an active role of $\mathrm{NO}_{x}$ in the plume chemistry. Specifically, the negative $\mathrm{NO}_{2}$ amounts 10 might result from its reaction with $\mathrm{BrO}$, enhancing the "bromine explosion" and converting $\mathrm{NO}_{\mathrm{x}}$ into nitric acid (which has also been detected close to source; Witham, 2005). Based on a mean optical path through the plume of $600 \mathrm{~m}$, we estimate a characteristic $\mathrm{BrO}$ mixing ratio of $\sim 2.3 \mathrm{ppbv}$, roughly double that observed in other tropospheric volcanic plumes. Based on the observed $\mathrm{BrO} / \mathrm{SO}_{2}$ ratio and the long term $\mathrm{SO}_{2}$ emission

15 rate from Kilauea, we estimate that the volcano emits on the order of $480 \mathrm{Mg} \mathrm{yr}^{-1}$ of reactive bromine, suggesting that it might play a significant role in local ozone depletion and $\mathrm{NO}_{\mathrm{x}}$ to $\mathrm{HNO}_{3}$ conversion. The observation of $\mathrm{BrO}$ in emissions from a relatively halogen-poor magma confirms predictions for Kilauea based on thermodynamic arguments (Gerlach, 2004) and extends the database on the global volcanogenic reactive bromine source to include a hotspot volcano for the first time.

Acknowledgements. We warmly acknowledge Natural Environment Research Council for providing support for this work via an urgent grant "Summit eruption of Kilauea volcano", and M. Edmonds for leading the project. VIT and CO are additionally funded by the NERC National Centre for Earth Observation. TJR acknowledges EU Marie Curie Initial Stage Training 25 Network Award NSINK (FP7 215503). We thank the staff of Hawaiian Volcano Observatory for their assistance and support in the field, especially J. Kauahikaua and M. Patrick. C. Werner and M. Boichu provided further field support. We are grateful to M. Burton, L. Spampinato, N. Browboski, and A. La Spina, for fruitful discussions, and to C. Fayt and M. van Roozendeal (I.S.A.B.) for providing the WinDoas software and for further discussions. We thank S. Calvari

\section{Enhancement of volcanogenic "bromine explosion" via reactive nitrogen}

G. G. Salerno et al.

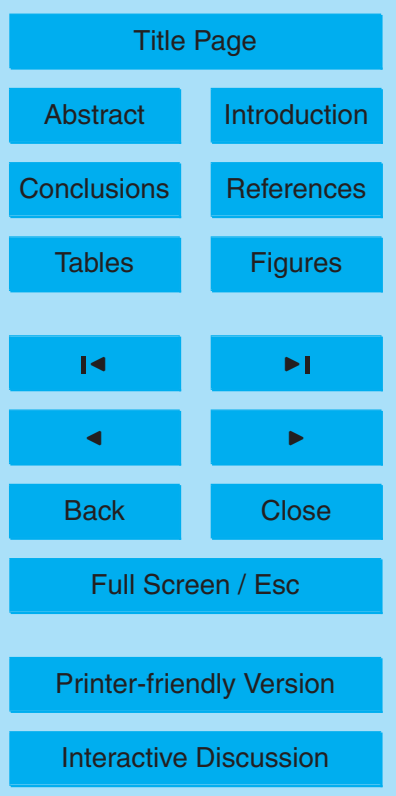


for encouragement and support. GGS thanks the Dipartimento di Protezione Civile della Regione Sicilia for support via the project "Sviluppo di sistemi di monitoraggio". Finally, both GGS and $\mathrm{CO}$ acknowledge additional support from the NOVAC (Network for Observation of Volcanic and Atmospheric Change) project of the EU Sixth Framework Programme.

\section{References}

Aiuppa, A.: Degassing of halogens from basaltic volcanism: Insights from volcanic gas observations, Chem. Geol., 263, 99-109, doi:10.1016/j.chemgeo.2008.08.022, 2008a.

Aiuppa, A., Baker, D. R., and Webster, J. D.: Halogens in volcanic systems, Chem. Geol., 263, 1-18, doi:10.1016/j.chemgeo.2008.10.005, 2008b.

Bani, P., Oppenheimer, C., Tsanev, V. I., Carn, S. A., Cronin, S. J., Crimp, R., Calkins, J. A., Charley, D., Lardy, M., and Roberts, T. R.: Surge in sulphur and halogen degassing from Ambrym volcano, Vanuatu. Bull. Volcanol., 71(10), 1159-1168, doi:10.1007/s00445009-0293-7, 2009.

Bobrowski, N., Hönninger, G., Galle, B., and Platt, U.: Detection of bromine monoxide in a volcanic plume, Nature, 423, 273-276, 2003.

Bobrowski, N., von Glasow, R., Aiuppa, A., Inguaggiato, S., Louban, I., Ibrahim, O. W., and Platt, U.: Reactive halogen chemistry in volcanic plumes, J. Geophys. Res., 112, D06311, doi:10.1029/2006JD007206, 2007a.

Bobrowski, N. and Platt, U.: $\mathrm{SO}_{2} / \mathrm{BrO}$ ratios studied in five volcanic plumes, J. Volcanol. Geoth. Res., 166, 147-160, doi:10.1016/j.jvolgeores.2007.07.003, 2007b.

Bobrowski, N. and Giuffrida, G.: Halogen/sulphur ratios in connection to volcanological observations 2006-2009 at Etna volcano, Conferenza Rittmann "La vulcanologia italiana: stato dell'arte e prospettive future", Istituto Nazionale di Geofisica e Vulcanologia - sezione di Catania, 11-13 June 2009, Nicolosi, Italy, 2009.

25 Bogumil, K., Orphal, J., and Burrows, J. P.: Temperature-dependent absorption cross-sections of $\mathrm{O}_{3}, \mathrm{NO}_{2}$, and other atmospheric trace gases measured with the SCIAMACHY spectrometer, in Proceeding of ERS-ENVISAT Symposium: Looking down to Earth in the New Millenium, Gothenburg, Sweden, 16-20 October, 2000.

\section{Enhancement of volcanogenic "bromine explosion" via reactive nitrogen}

G. G. Salerno et al.

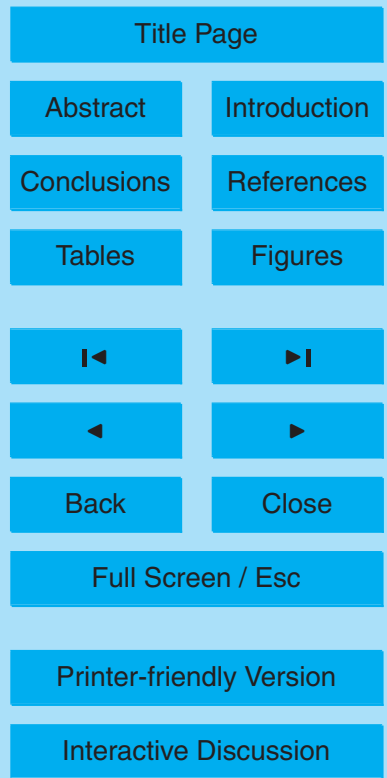


Bureau, H., Keppler, H., and Metrich, N.: volcanic degassing of bromine and iodine: experimental fluid/melt partitioning data and applications to stratospheric chemistry, Earth Planet. Sci. Lett., 183, 51-60, 2000

Cadle, R. D.: A Comparison of Volcanic With Other Fluxes of Atmospheric Trace Gas Constituents, Rev. Geophys., 18(4), 746-752, 1980.

Carroll, M. A., Ridley, B. A., Montzka, D. D., Hubler, G., Walega, J. G., Norton, R. B., Huebert, B. J., and Grahek, F. E.: Measurements of Nitric Oxide and Nitrogen Dioxide During the Mauna Loa Observatory Photochemistry Experiment, J. Geophys. Res., 97(D10), 10361-10374, 1992.

10 Carroll, M. R. and Holloway, J. R.: Volatiles in magmas, Reviews of Mineralogy, 30, Mineral Society of America, Washington, DC, 1994.

Chance, K.: Analysis of $\mathrm{BrO}$ measurements from the Global Ozone Monitoring Experiment, Geophys. Res. Lett., 25, 3335-3338, 1988.

Elias, T. and Sutton, A. J.: Sulfur Dioxide emission rates of Kilauea Volcano, Hawaii, an update: 1998-2001, US Geological Survey, Open File Rep. 02-460, 2002.

Elias, T. and Sutton, A. J.: Sulfur Dioxide emission rates of Kilauea Volcano, Hawaii, an update: 2002-2006, US Geological Survey, Open File Rep. 2007-1114, 37, 2007.

Elias, T. and Sutton, A. J.: Sulfur Dioxide Emission Rates from Kilauea Volcano, Hawaii 20072009, US Geological Survey, Open File Rep., in preparation, 2010.

20 Fayt, C. and Van Roozendael, M.: WinDOAS 2.1 - Software User Manual, Institut d'Aéronomie Spatiale de Belgique, Brussels, Belgium, 2001.

Fish, D. J. and Jones, R. L.: Rotational Raman scattering and the ring effect in zenith-sky spectra, Geophys Res. Lett., 22, 811-814, 1995.

Gerlach, T. M. and Graeber, E. J.: Volatile budget of Kilauea volcano, Nature, 313, 273-277, 251985.

Gerlach, T. M.: Volcanic sources of tropospheric ozone-depleting trace gases, Geochem. Geophys. Geosy., 5(9), Q09007, doi:10.1029/2004GC000747, 2004.

Grainger, R. G. and Highwood, E. J.: Changes in stratospheric composition, chemistry, radiation and climate caused by volcanic eruptions, in: Volcanic degassing, edited by: Oppenheimer, C., Pyle, D. M., and Barclay, J., Geol. Soc. Spec. Publ., 213, 329-347, 2003.

Hedenquist, J. W. and Lowenstern, J. B.: The role of magmas in the formation of hydrothermal ore deposits, Nature, 370, 519-527, 1994.

\section{Enhancement of volcanogenic "bromine explosion" via reactive nitrogen}

G. G. Salerno et al.

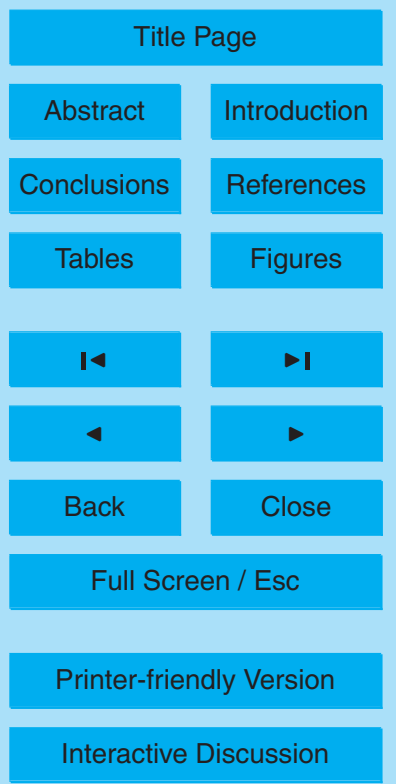


Heliker, C., Swanson, D. A., and Takahashi, T. J.: The Pu'u O'o-Kupaianaha eruption of Kīlauea Volcano, Hawai'i: The first 20 years, Professional paper; 1676, United States Geological Survey, 2003.

Hilton, D. R., Fisher, T. P., and Marty, B.: Noble gases and volatile recycling at subduction zones: Reviews in Mineralogy and geochemistry, 47, 319-370, 2002.

Huebert, B., Vitousek, P., Sutton, J., Elias, T., Heath, J., Coeppicus, S., Howell, S., and Blomquist, B.: Volcano fixes nitrogen into plant-available forms, Biogeochemistry, 47, 111118, 1999.

Kelly, P. M.: Volcanic dust veil and North Atlantic climatic change, Nature, 268, 616-617, 1977.

Kern, C., Sihler, H., Vogel, L., Rivera, C., Herrera, M., and Platt, U.: Halogen oxide measurements at Masaya Volcano, Nicaragua using active long path differential optical absorption spectroscopy, Bull. Volcanol., 71(6), 659-670, doi:10.1007/s00445-008-0252-8, 2008.

Kern, C., Deutschmann, T., Vogel, L., Wöhrbach, M., Wagner, T., and Platt, U.: Radiative transfer corrections for accurate spectroscopic measurements of volcanic gas emissions, Bull. Volcanol., 72(2), 233-247, doi:10.1007/s00445-009-0313-7, 2009.

Marti, J. and Ernst, G. G. J.: Volcanoes and the Environment, Cambridge University Press, Cambridge, 2005.

Martin, R. S., Mather, T. A., and Pyle, D. M.: High-temperature mixtures of magmatic and atmospheric gases, Geochem. Geophys. Geosys., 7, Q04006, doi:10.1029/2005GC001186, 2006.

Martin, R. S., Roberts, T. J., Mather, T. A., and Pyle, D. M.: The implications of $\mathrm{H}_{2} \mathrm{~S}$ and $\mathrm{H}_{2}$ kinetic stability in high-T mixtures of magmatic and atmospheric gases for the production of oxidized trace species (e.g., BrO and $\mathrm{NO}_{\mathrm{x}}$ ), Chem. Geol., 263, 143-150, 2009.

Mather, T., Pyle, D. M., and Oppenheimer, C.: Tropospheric volcanic aerosol, in: Volcanism and the Earth's Atmosphere, edited by: Robock, A. and Oppenheimer, C., American Geophysical Union Monograph, USA, 139, 189-212, 2003.

Mather, T. A., Allen, A. G., Pyle, D. M., Davison, B. M., Oppenheimer, C., and McGonigle, A. J. S.: Nitric acid from volcanoes, Earth Planet. Sci. Lett., 218, 17-30, 2004.

Muranatsu, Y. and Wedepohl, K. H.: The distribution of iodine in the Earth's crust, Chem. Geol. 147, 201-216, 1998.

Noxon, J. F.: Nitrogen dioxide in stratosphere and troposphere measured by ground-based absorption spectroscopy, Science, 189, 547-549, 1975.

\section{Enhancement of volcanogenic "bromine explosion" via reactive nitrogen}

G. G. Salerno et al.

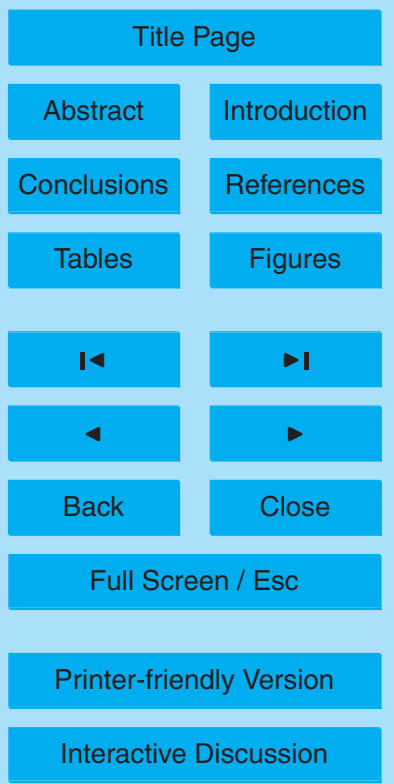


Oppenheimer, C.: Volcanic degassing, in: The Crust Vol. 3, Treatise on Geochemistry, edited by: Rudnick, R. L., Elsevier-Pergamon, Oxford, 123-166, 2003.

Oppenheimer, C., Kyle, P. R., Tsanev, V. I., McGonigle, A. J. S., Mather, T. A., and Sweeney, D.: Mt. Erebus, the largest point source of $\mathrm{NO}_{2}$ in Antarctica, Atmos. Environ., 39, 6000-6006, 52005.

Oppenheimer, C., Tsanev, V. I., Braban, C. F., Cox, R. A., Adams, J. W., Aiuppa, A., Bobrowski, N., Delmelle, P., Barclay, J., and McGonigle, A. J.: BrO formation in volcanic plumes, Geochim. Cosmochim. Acta, 70(12), 2935-2941, 2006.

Oppenheimer, C., Kyle, P., Eisele, F., Crawford, J., Huey, G., Tanner, D., Kim, S., Mauldin, L., Blake, D., Beyersdorf, A., Buhr, M., and Davis, D.: Atmospheric chemistry of an Antarctic volcanic plume, J. Geophys. Res., 115, D04303, doi:10.1029/2009JD011910, 2010.

Orr, T., Patrick, M., Wooten, K. M., Swanson, D. A., Elias, T., Sutton, A. J., Wilson, D. C., and Poland, M. P.: Explosions, Tephra, and Lava: A Chronology of the 2008 Summit Eruption of Kilauea Volcano, Hawai'i, AGU Fall Meeting, 15-19 December 2008, San Francisco, USA, 15 V11B-2018, 2008.

Patrick, M., Wilson, D., Fee, D., Orr, T., Swanson, D., Sutton, A., and Elias, T.: Gas-Pistoning associated with the 2008 summit eruption of Kllauea volcano (Hawai'i), AGU Fall Meeting, 15-19 December 2008, San Francisco, USA, V51E-2082, 2008.

Perner, D. and Platt, U.: Detection of Nitrous Acid in the Atmosphere by Differential Optical Absorption, Geophys. Res. Lett., 6, 917-920, 1979.

Plane, J. M. C. and Saiz-Lopez, A.: UV-Visible Differential Optical Absorption Spectroscopy (DOAS), in: Analytical Techniques for Atmospheric Measurement, edited by: Heard, D., Blackwell Publishing, 2006.

Platt, U.: Differential Optical absorption spectroscopy (DOAS), in: Air monitoring by spectroscopy techniques, Chemical analysis Series 127, edited by: Sigrist, M. W., Wiley, New York, 27-84, 1994.

Platt, U. and Stutz, J.: Differential Optical Absorption Spectroscopy Principles and Applications, Series: Physics of Earth and Space Environments, Springer, 2008.

Poland, M. P. and Sutton, A. J.: Kilauea activity during 2007-2008: A failed eruption and an eruption should have failed, 2008, AGU Fall Meeting, 15-19 December 2008, San Francisco, USA, V51D-2073, 2008.

Pyle, D. M. and Mather, T. A.: Halogens in igneous processes and their fluxes to the atmosphere and oceans from volcanic activity: A review, Chem. Geol., 263(1-4), 110-121, 2009.

\section{ACPD}

10, 10313-10334, 2010

\section{Enhancement of volcanogenic \\ "bromine explosion" via reactive nitrogen}

G. G. Salerno et al.

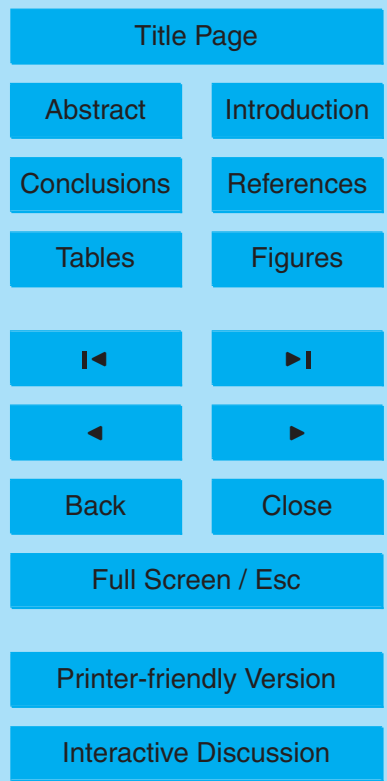


Roberts, T. J., Braban, C. F., Martin, R. S., Oppenheimer, C., Adams, J. W., Cox, R. A., Jones, R. L., and Griffths, P. T.: Modelling reactive halogen formation and ozone depletion in volcanic plumes, Chem. Geol. 263, 151-163, 2009.

Solomon, S., Schmeltekopf, A. L., and Sanders, R. W.: On the interpretation of zenith sky absorption measurements, J. Geophys. Res., 92, 8311-8319, 1987.

Sugiura, T., Mizutani, Y., and Oana, S.: Fluorine, chlorine, bromine and iodine in volcanic gases, Nagoya Univ., J. Earth. Sci, 11, 272, 1963.

Sutton, A. J., Elias, T., Gerlach, T. M., Stockes, J. B.: Implications for eruptive process as indicated by sulfur dioxide emissions form Killauea Volcano, Hawaii, 1979-1997, J. Volcanol.

10 Geoth. Res., 108, 283-302, 2001.

Symonds, R. B., Rose, W. I., Bluth, G., and Gerlach, T. M.: Volcanic gas studies: methods, results, and applications, in: Volatiles in Magmas: Mineralogical Society of America Reviews in Mineralogy, edited by: Carroll, M. R. and Holloway, J. R., 30, 1-66, 1994.

Snyder, G. T. and Fehn, U.: Origin of iodine in volcanic fluids: 129 l results from the Central American Volcanic arc, Geochim. Cosmochim. Acta, 21, 3827-3838, 2002.

Theys, N., Van Roozendael, M., Dils, B., Hendrick, F., Hao, N., and De Mazière, M.: First satellite detection of volcanic bromine monoxide emission after the Kasatochi eruption, Geophys. Res. Lett., 36, L03809, doi:10.1029/2008GL036552, 2009.

Vogel, L., Kern, C., Fickel, M., Wöhrbach, M., and Platt, U.: Halogen oxides in volcanic plumes: 20 Simultaneous measurements at different plume ages, AGU Fall Meeting, 15-19 December 2008, San Francisco, USA, A51C-0102, 2008.

von Glasow, R., Bobrowski, N., and Kern, C.: The effects of volcanic eruptions on atmospheric chemistry, Chem. Geol., 263, 131-142, 2009.

Wahner, A. R., Ravishankara, A., Sander, S. P., and Friedl, R. R.: Absorption cross section of BrO; between 312 and $385 \mathrm{~nm}$ at 298 and $223 \mathrm{~K}$, Chem. Phys. Lett., 152, 507-512, 1988.

Wedepohl, K. H.: Handbook of Geochemistry, II/4, 35-E-1 to 35-E-5 and 53-E-3 to 53-E-5, 1974.

Wennberg, P.: Bromine explosion, Nature, 397, 299-300, 1999.

Wehrmann, H.: Volatile degassing and plinian eruption dynamics of the mafic Fontana Tephra, Nicaragua, Ph. D, University of Kiel, Germany, 2005.

Witham, C. S.: Volcanic plumes: impacts, chemistry and dispersion, Ph. D, University of Cambridge, 2005.

\section{Enhancement of volcanogenic "bromine explosion" via reactive nitrogen}

G. G. Salerno et al.

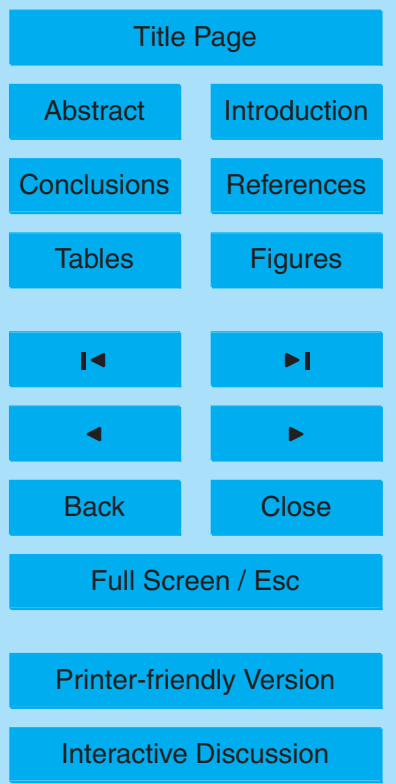


Table 1. Summary of $\mathrm{BrO}, \mathrm{SO}_{2}$, and $\mathrm{NO}_{2}$ retrievals for spectra collected at Pu'u'O'ō and Halema'uma'u on 3 September 2007 and 13 May 2008, respectively. Geographic location, timing of data collection, and environmental and chemical parameters are given. See Fig. 1 for location map.

\begin{tabular}{|c|c|c|}
\hline parameter & Pu'u'Ō'ō & Halema'uma'u \\
\hline day of collection & 3 Sep 2007 & 13 May 2008 \\
\hline time data collection (LT) & $15: 00-15: 30$ & $10: 45-12: 10$ \\
\hline age of the plume $(\mathrm{min})$ & $\sim 2$ & $\sim 8$ \\
\hline weather & Mostly Cloudy & Partly Sunny \\
\hline Coordinates (Latitude and Longitude) & $19.38 \mathrm{~N}: 155.111 \mathrm{~W}$ & $19.42 \mathrm{~N} ; 155.289 \mathrm{~W}$ \\
\hline Temp. $\left({ }^{\circ} \mathrm{C}\right)$ and Relative Humidity & $25 ; 80 \%$ & $20 ; 72 \%$ \\
\hline $\min \mathrm{SO}_{2} \mathrm{SCA}$ & $1 \times 10^{16}$ & $1 \times 10^{17}$ \\
\hline $\max \mathrm{SO}_{2} \mathrm{SCA}$ & $3 \times 10^{18}$ & $7 \times 10^{18}$ \\
\hline mean $\mathrm{SO}_{2} \mathrm{SCA}$ & $8 \times 10^{17}$ & $3 \times 10^{18}$ \\
\hline $\min \mathrm{BrO} \mathrm{SCA}$ & & $7 \times 10^{14}$ \\
\hline $\max \mathrm{BrO} \mathrm{SCA}$ & & $5 \times 10^{15}$ \\
\hline mean $\mathrm{BrO}$ SCA & & $3 \times 10^{15}$ \\
\hline $\min \mathrm{NO}_{2} \mathrm{SCA}$ & & $-1 \times 10^{17}$ \\
\hline $\max \mathrm{NO}_{2} \mathrm{SCA}$ & & $7 \times 15^{15}$ \\
\hline mean $\mathrm{NO}_{2} \mathrm{SCA}$ & & $-6 \times 10^{16}$ \\
\hline $\mathrm{BrO} / \mathrm{SO}_{2}\left(\mathrm{~mol} \mathrm{~mol}^{-1}\right)$ & & $\sim 5 \times 10^{-4}$ \\
\hline $\mathrm{SO}_{2} / \mathrm{BrO}\left(\mathrm{mol} \mathrm{mol}^{-1}\right)$ & & 1600 \\
\hline$R^{2}$ & & 0.84 \\
\hline $\mathrm{SO}_{2} / \mathrm{NO}_{2}$ ratio $\left(\mathrm{mol} \mathrm{mol}^{-1}\right)$ & & -49 \\
\hline$R^{2}$ & & 0.87 \\
\hline $\mathrm{NO}_{2} / \mathrm{BrO}$ ratio $\left(\mathrm{mol} \mathrm{mol}^{-1}\right)$ & & -30 \\
\hline$R^{2}$ & & 0.84 \\
\hline BrO Flux $\left(\mathrm{g} \mathrm{s}^{-1}\right)$ & & 8.5 \\
\hline $\mathrm{BrO}$ mixing ratio $(\mathrm{ppb})$ & & 2.30 \\
\hline $\mathrm{S} / \mathrm{Br}$ mass ratio & & 645 \\
\hline $\mathrm{SO}_{2}$ mixing ratio $(\mathrm{ppb})$ & 1320 & 2140 \\
\hline
\end{tabular}

ACPD

10, 10313-10334, 2010

\section{Enhancement of volcanogenic "bromine explosion" via reactive nitrogen}

G. G. Salerno et al.

Title Page

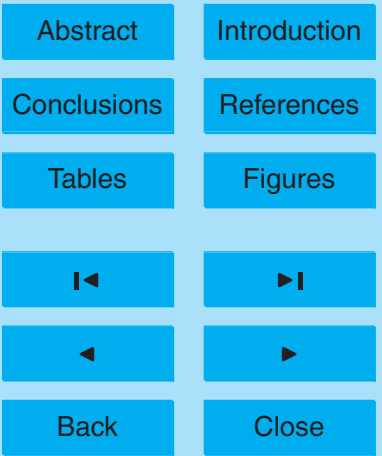

Full Screen / Esc

Printer-friendly Version

Interactive Discussion

$\mathrm{SCA}=$ Slant Column Amount (molecules $\mathrm{cm}^{-2}$ ) 


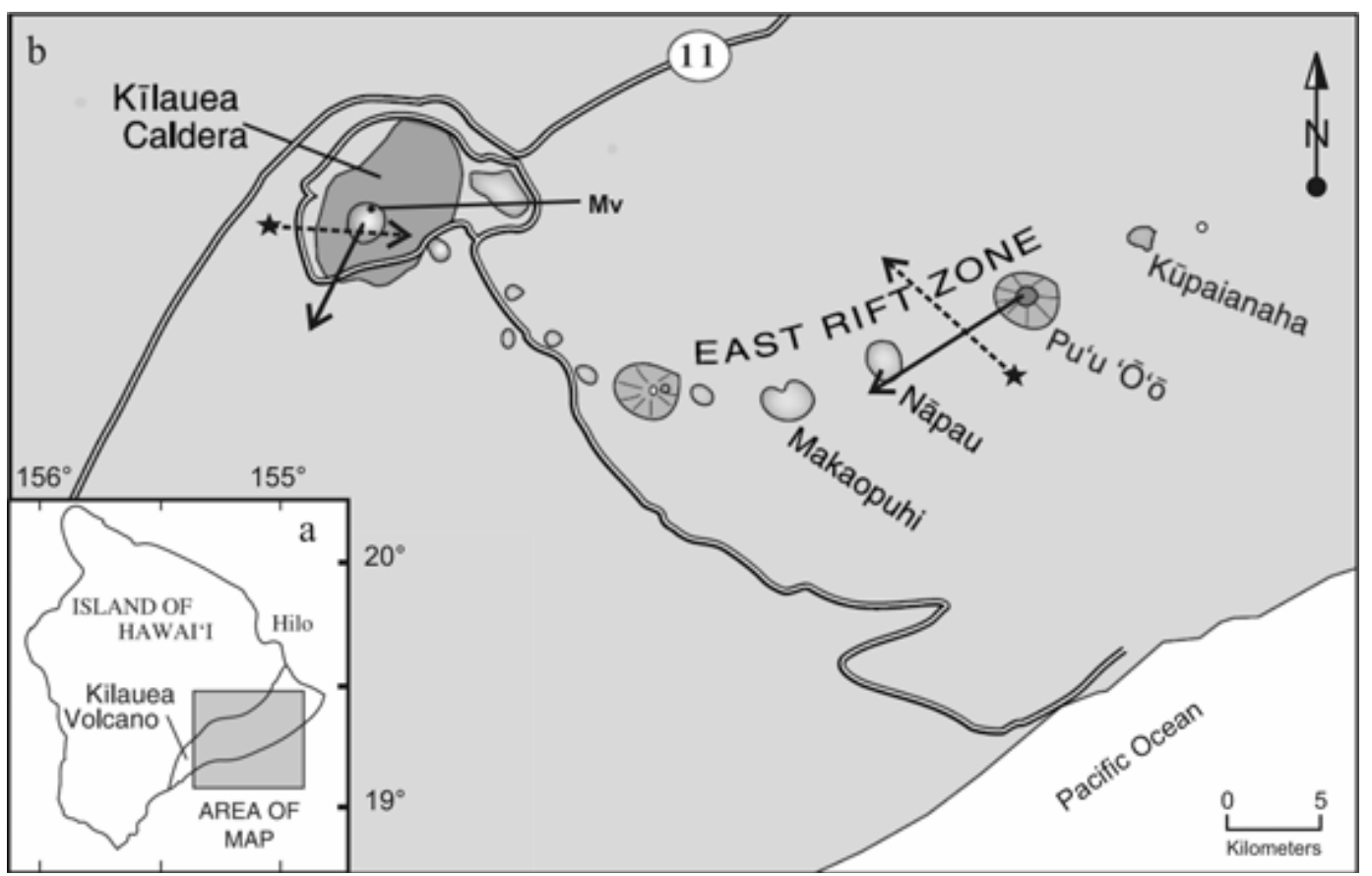

Fig. 1. (a) Map of the Island of Hawai'i showing the location of Kllauea Volcano (b), the Halema'uma'u Summit caldera, the East Rift Zone, and the Pu'u'Ō'ō cone. Solid stars indicate the sites from which UV spectra were collected in 2007 and 2008. Dotted arrows represent the two different viewing directions; approximate direction of plume dispersion is shown by the other arrows. The label $\mathrm{Mv}$ denotes the location of the magmatic vent in the caldera; during the period of survey it measured about 20-30 m in diameter (modified after Thornber, 2003).

\section{ACPD}

10, 10313-10334, 2010

\section{Enhancement of volcanogenic} "bromine explosion" via reactive nitrogen

G. G. Salerno et al.

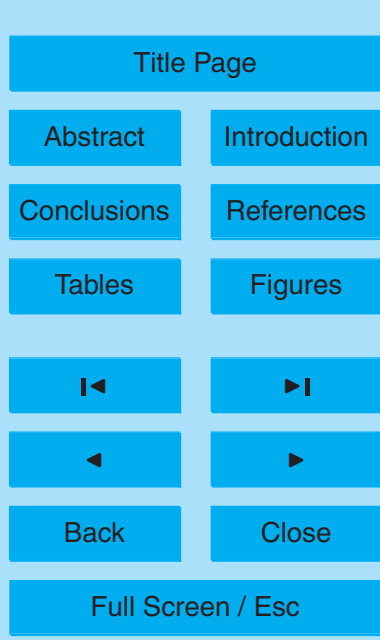

Printer-friendly Version

Interactive Discussion 


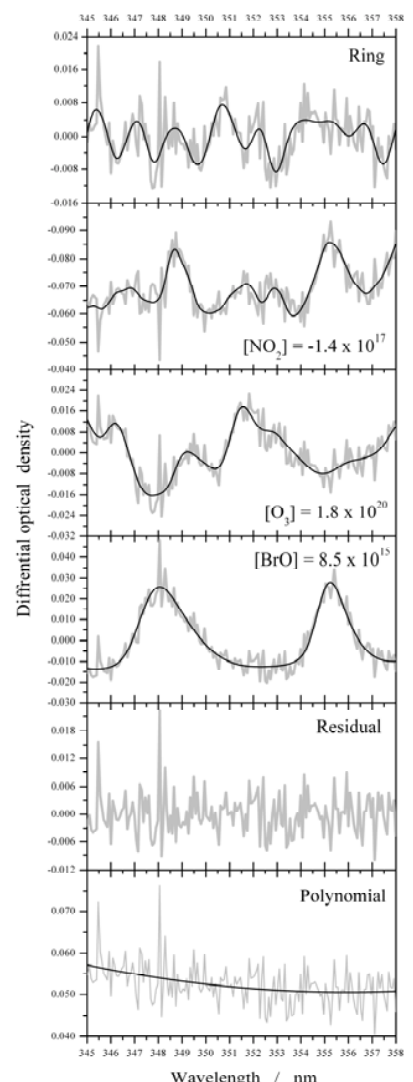

Wavelength / $\mathrm{nm}$

Fig. 2. Example of fitting process for a spectrum with high volcanic gas content. The spectrum was collected in the plume emitted from the new magmatic vent in Halema'uma'u crater on 13 May 2008. The measured differential optical density (grey curves) is fitted by the Ring, $\mathrm{NO}_{2}, \mathrm{O}_{3}$, and $\mathrm{BrO}$ differential laboratory spectra (black curves). The residual after fitting shows random modulation, validating the quality of the fit. Systematic structures at $\sim 345.5$ and $\sim 348.0 \mathrm{~nm}$ are due to instrumental noise (hot pixels). A second order polynomial was applied to subtract low frequency contributions to the atmospheric attenuation due to Rayleigh and Mie scattering. The high differential ozone SCA results from the difference in the optical paths through the whole atmosphere of the CSR compared with the throughthe-plume spectra.
ACPD

10, 10313-10334, 2010

\section{Enhancement of volcanogenic "bromine explosion" via reactive nitrogen}

G. G. Salerno et al.

\section{Title Page}

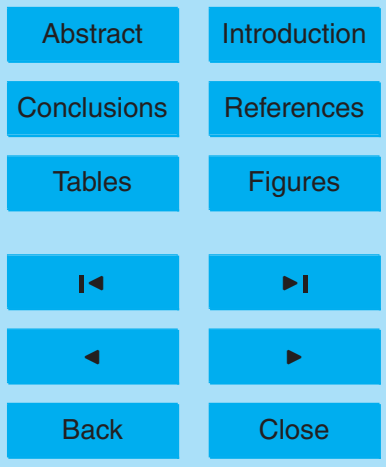

Full Screen / Esc

Printer-friendly Version

Interactive Discussion 


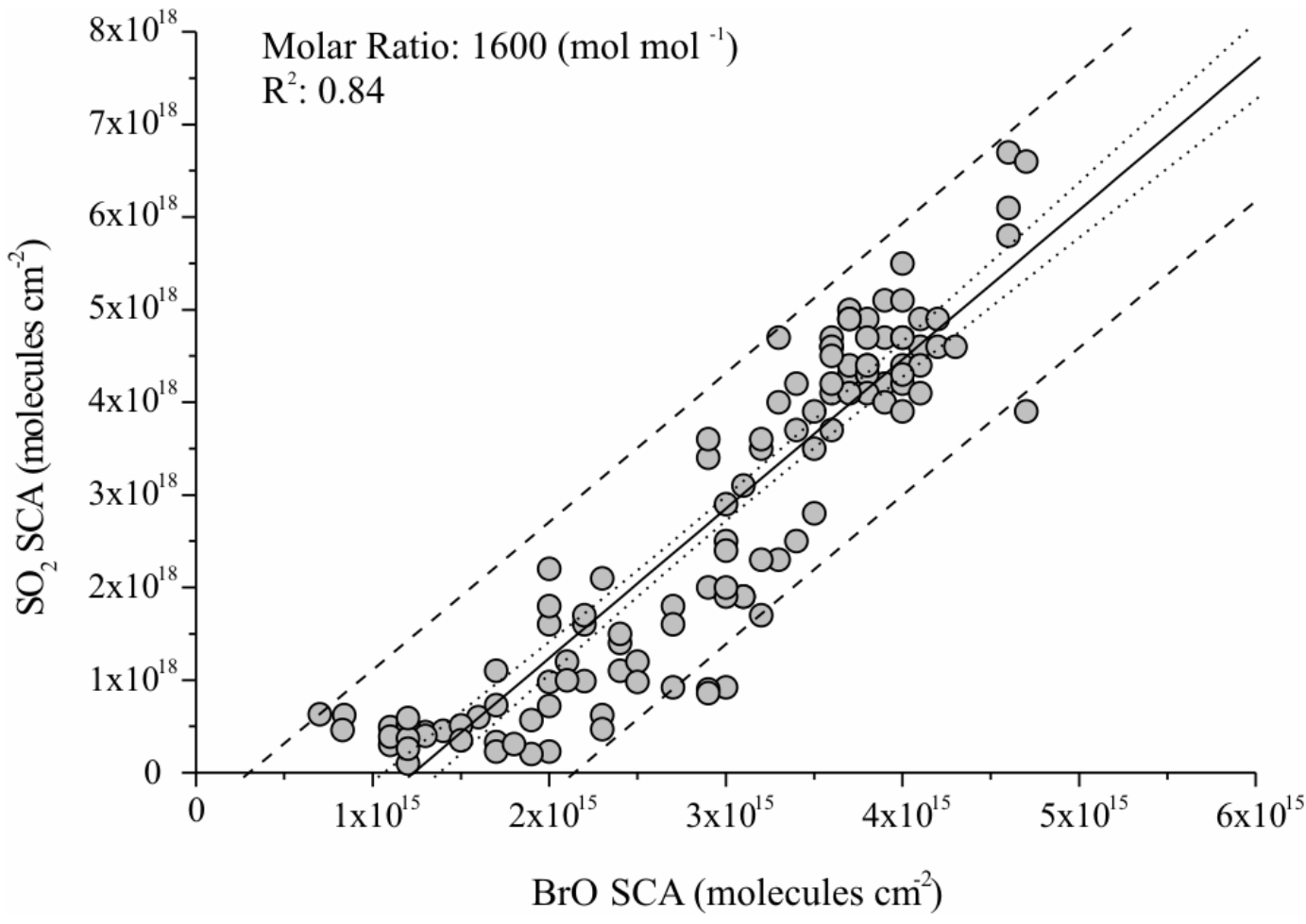

Fig. 3. Scatter plot of $\mathrm{SO}_{2}$ versus BrO SCA for data collected on 13 May 2008 at Halema'uma'u. The species are strongly correlated $\left(R^{2}=0.84\right)$ and are fit by linear regression (solid line) indicating $\mathrm{SO}_{2} / \mathrm{BrO}=1600 \mathrm{~mol} \mathrm{~mol}^{-1}$. The dotted and dashed lines represent prediction and $95 \%$ confidence limits of the regression, respectively. The scatter is believed to reflect the influence of environmental and volcanological effects and associated variability of $\mathrm{SO}_{2}$ and $\mathrm{BrO}$ mixing ratios within the plume. The intercept is discussed in the text.

\section{ACPD}

10, 10313-10334, 2010

\section{Enhancement of volcanogenic "bromine explosion" via reactive nitrogen}

G. G. Salerno et al.

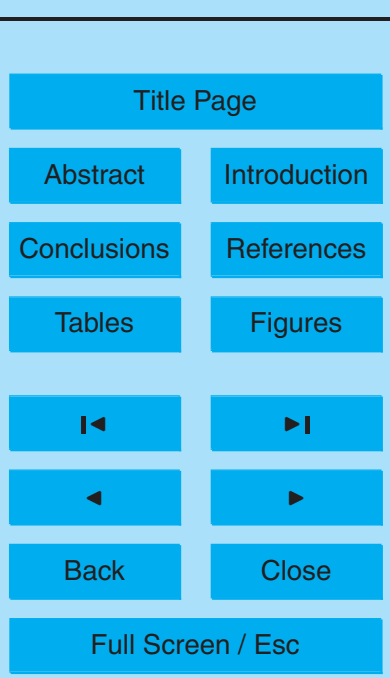

Printer-friendly Version

Interactive Discussion 


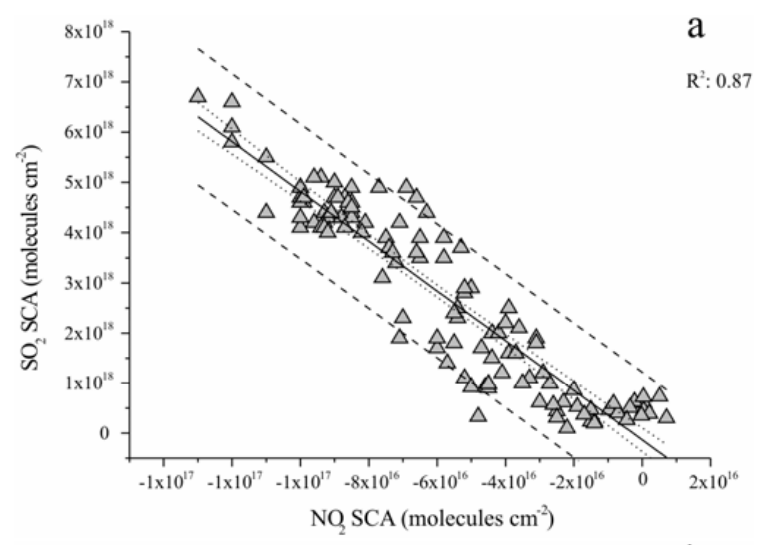

\section{ACPD}

10, 10313-10334, 2010

\section{Enhancement of volcanogenic "bromine explosion" via reactive nitrogen}

G. G. Salerno et al.

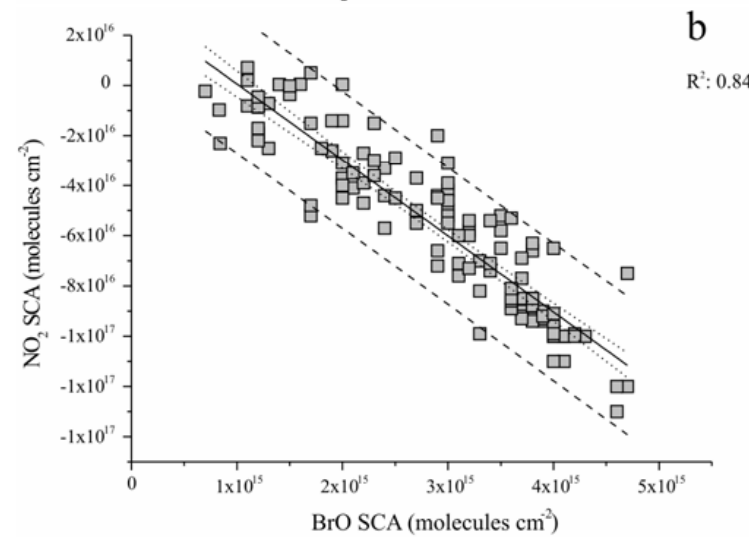

Title Page

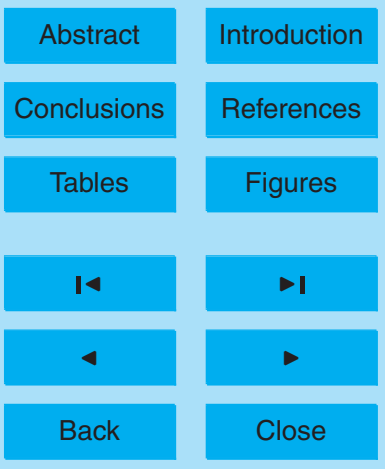

Full Screen / Esc

Fig. 4. Scatter plots showing $\mathrm{SCA}$ of (a) $\mathrm{SO}_{2}$ versus $\mathrm{NO}_{2}$, and (b) $\mathrm{NO}_{2}$ versus $\mathrm{BrO}$. The retrieved $\mathrm{NO}_{2} \mathrm{SCA}$ at Halema'uma'u, is strongly anti-correlated with both $\mathrm{SO}_{2}$ and $\mathrm{BrO}\left(R^{2}=0.87\right.$ and 0.84 , respectively). This close relationship between the three species, suggests active involvement of $\mathrm{NO}_{\mathrm{x}}$ in reactive bromine formation. The solid lines indicate the linear regression fitted to the data, and the dotted and dashed lines represent prediction and $95 \%$ confidence limits of the regression, respectively.

Printer-friendly Version

Interactive Discussion 